Egypt. Acad. J. biolog. Sci., 2 (2): 171-175 (2009)

Email: egyptianacademic@yahoo.com

Received: 30/11/2009
A. Entomology

ISSN: $1687-8809$

www.eajbs.eg.net

\title{
Effect of Bermuda Grass Cynodon dactylon Extracts on Cotton Leaf Worm, Spodoptera littoralis Boisduval (Lepidoptera: Noctuidae)
}

\author{
Noeman B. AREF \\ Pests and Plant protection Dept., National Research Center, Giza, Egypt.
}

\begin{abstract}
Bermuda grass, Cynodon dactylon (L.) extracts were tested on cotton leaf worm, Spodoptera littorals (Boisd.). Five solvents were used in preparing of these extracts, (i.e., methanol, petroleum ether, acetone, diethyl ether and distilled water). Distilled water was used as polar solvent. The results showed that extracts of non polar solvents were more effective than water. Methanol extract resulted in highest number of giant larvae. Methanol and diethyl ether extracts resulted in the highest number of deformed pupae.

Acetone extract caused highest number of mortalities, followed by diethyl ether and methanol extracts. Methanol extract proved to be the most efficient on fertility of $S$. littorals. All extracts had a slight effect on the larval and pupal stages duration compared with control. Larval and pupal weights were affected in the same manner also. It was concluded that all extracts caused a disturbance in hormonal balance in the larvae.
\end{abstract}

Keywords: Spodoptera littoralis, Cynodon dactylon

\section{INTRODUCTION}

Bermuda grass, Cynodon dactylon (L.) (Fam. Geramineae) has shown to play different roles biologically, physiologically, insecticidaly in animal control (Mueller and Dumas, 1987; Chang, 1986; and Singh et al., 2008). Walter (1962) isolated four components from C. dactylon. These include B. sitosteral, B. sitosteryl, D. glucoside and palmitic acid. Negulescu and Pisohi (2008) found that this grass also contains selenium and arsenic selenium.

Effect of this grass on fall army worm larvae and the relationship of its quality to the larval developmental parameters was studied by Lynche et al. (1983 and 1986).

Cynodon plant was also used to investigate host associated genetic differentiation and developmental and reproductive traits in fall armyworm strains (Pashly, 1986; and Pashly et al., 1995). Excellent work was experimentally done on consumption, utilization, biology and economic injury levels of fall army worm on Bermuda grasses by Jamjanya (1987) and Jamjanya and Quisenberry (1988). This grass was also used as host plant for Spodoptera exempta (Walker) in biological control studies using highly effective strains of Bacillus thuringiensis (Broza et al., 1991)

The present paper is concerned with demonstrating the effect of five extracts of Bermuda grass using different non polar and polar solvents on morphogenetic and fertility of Spodoptera littoralis Boisd.

\section{MATERIALS AND METHODS}

\section{Experimental animals:}

Larvae of the cotton leaf worm S. littoralis were obtained from culture bred and constantly maintained for several years under laboratory conditions according to 
the procedure of El-Ibrashy and Chenouda (1970). They were fed on fresh castor-oil leaves and kept at $30-+1{ }^{\circ} \mathrm{C}$ and $65 \pm 5 \% \mathrm{RH}$. The tested larvae were individually placed in glass vials $(10 \times 2.7 \mathrm{~cm}$ each). Tightly covered with muslin mesh for daily inspections and weightings.

\section{Preparation of plant extracts:}

Bermuda grass, C. dactylon (Fam. Geramineae) was planted in clay soil in the experimental plots at National Research Center. After one month, grass was collected and the leaves were separated from roots. Plant leaves were allowed to dry for ten days at room temperature. Dried leaves were separated manually and crashed by house hold grinder. Hundred grams crashed plant leaves were soaked in $200 \mathrm{ml}$ of each solvent as methanol, petroleum ether (60-80), acetone, diethyl ether and distillated water for 48 hours, with continuous stirring. Filtration was then carried out through very fine gauze. All extracts were kept in a dry cold place.

\section{Treatments:}

Castor-oil leaves discs ( $2 \mathrm{~cm}$ diameter) were prepared using cork corer and each was weighted. By micro pipette one $(\mu 1)$ of each extract was applied to each caster oil disc. A new moulted $4^{\text {th }}$ instar larva was located on each disc. The experimental discs were then placed individually in cups $(120 \mathrm{ml})$ and each was weighted before and after introducing the larvae, during the first $24^{\text {th }}$ hour. (El- Gammal et al., 1988). After $24^{\text {th }}$ the larvae were fed on untreated castor leaves. The percents of mortalities were calculated in the end of the experiment.

\section{Statistical analysis}

Data were analyzed by analysis of variance (one way classification ANOVA) and followed by a least significant difference (L.S.D at 5\%) (SAS Institute Inc., 2003).

\section{RESULTS}

The obtained data showed that the highest number of mortalities occurred when acetone (7), methanol (5), diethyl ether (5) followed by water (3) and petroleum ether extracts were used (Table 1). Data also proved that non polar extracts affected the hormonal balance of treated larvae resulted in occurrence of deformed and giant larvae. The highest numbers of giant larvae were when methanol extract (12) was used. The highest number of deformed larvae was obtained when methanol and diethyl ether extracts (3) were used. On the other hand, the lowest number of giant larvae was found after using water, acetone and petroleum ether extract.

The number of laid eggs were highest when water was used followed by diethyl ether, petroleum ether, acetone.

Table (1): Biological parameters of Bermuda grass, C. dactylon (L.) extracts with different solvents on $4^{\text {th }}$ instar larvae of S. littoralis

\begin{tabular}{|c|c|c|c|c|c|}
\hline Extracts & Alive & ${ }^{* *}$ Mortalities & Deformation & Giant larvae & No. of laid eggs \\
\hline Methanol & 0 & 5 & 3 & 12 & 0.0 \\
\hline Petroleum ether & 9 & 0 & 1 & 10 & 10750 \\
\hline Acetone & 6 & 7 & 1 & 6 & 9516 \\
\hline Diethyl ether & 8 & 5 & 3 & 4 & 12543 \\
\hline Water & 13 & 3 & 1 & 3 & 15533 \\
\hline control & 19 & 1 & 0 & 0 & 22564 \\
\hline
\end{tabular}

*20 larvae were used in each extract treatments.

**Mortality was calculated when larvae reached at adult emergence. 
Statistical analysis (Table 2) revealed that both methanol and water reduced the time of $4^{\text {th }}$ instar larvae compared with control. These durations were 4.933 and 4.850 compared with 5.450 days, respectively. The fifth instar larvae durations by three non polar extracts (i.e., methanol, petroleum ether and diethyl ether) were not significantly different from the control. As far as the sixth instar and the prepupal stages, data revealed that all extracts had significantly reduced durations compared with the control. The longevity of the pupal stage was similar among affected by methanol, petroleum ether and acetone extracts resembling the control.

Results presented in data in Table 3 shows also that the weight of the different stages of $S$. littorals had been variously affected by the $C$. dactylon extracts. All non polar and water extracts have equal effect on the weight of the fourth instar resembling the control. As far as the fifth instar is concerned water and diethyl ether had equal low effect. Petroleum ether and acetone had intermediate effect resembling the untreated insects.

Table 2: Effect of Cynodon dactylon extracts on the duration of different stages of Spodoptera littoralis

\begin{tabular}{|c|c|c|c|c|c|}
\hline \multirow{2}{*}{ Extracts } & \multicolumn{2}{|c|}{ Larval duration (in days \pm SE) } & \multicolumn{2}{c|}{ Pupal stage (in days \pm SE) } \\
\cline { 2 - 6 } & $4^{\text {th }}$ instar & $5^{\text {th }}$ instar & $6^{\text {th }}$ instar & prepupa & Pupa \\
\hline Methanol & $4.933 \pm 0.07^{\mathrm{b}}$ & $5.733 \pm 0.12^{\mathrm{b}}$ & $9.188 \pm 0.36^{\mathrm{b}}$ & $3.0 \pm 0.24^{\mathrm{a}}$ & $24.154 \pm 0.59^{\mathrm{b}}$ \\
\hline Petroleum ether & $5.550 \pm 0.16^{\mathrm{a}}$ & $5.450 \pm 0.11^{\mathrm{b}}$ & $9.048 \pm 0.22^{\mathrm{b}}$ & $3.8 \pm 0.27^{\mathrm{a}}$ & $24.250 \pm 0.55^{\mathrm{b}}$ \\
\hline Acetone & $5.350 \pm 0.11^{\mathrm{a}}$ & $5.833 \pm 0.19^{\mathrm{ab}}$ & $8.722 \pm 0.28^{\mathrm{b}}$ & $2.944 \pm 0.21^{\mathrm{a}}$ & $24.222 \pm 0.42^{\mathrm{b}}$ \\
\hline Water & $4.850 \pm 0.11^{\mathrm{b}}$ & $6.150 \pm 0.11^{\mathrm{a}}$ & $9.150 \pm 0.21^{\mathrm{b}}$ & $2.350 \pm 0.15^{\mathrm{a}}$ & $26.20 \pm 0.53^{\mathrm{a}}$ \\
\hline Diethyl ether & $5.450 \pm 0.19^{\mathrm{a}}$ & $5.700 \pm 0.11^{\mathrm{b}}$ & $9.368 \pm 0.28^{\mathrm{b}}$ & $2.474 \pm 0.21^{\mathrm{a}}$ & $25.684 \pm 0.47^{\mathrm{ab}}$ \\
\hline control & $5.450 \pm 0.11^{\mathrm{a}}$ & $5.684 \pm 0.11^{\mathrm{b}}$ & $10.316 \pm 0.36^{\mathrm{a}}$ & $1.579 \pm 0.16^{\mathrm{b}}$ & $24.263 \pm 0.42^{\mathrm{b}}$ \\
\hline F. values & $4.845^{* *}$ & $3.565^{* *}$ & $3.656^{* *}$ & $6.416^{* *}$ & $3.413^{* *}$ \\
\hline
\end{tabular}

Table 3: Effect of Cynodon dactylon extracts on the weight $(\mathrm{g} \pm \mathrm{SE})$ of different stages of Spodoptera littoralis.

\begin{tabular}{|c|c|c|c|c|c|}
\hline \multirow{2}{*}{ Extracts } & \multicolumn{5}{|c|}{ Body Weight (g $\pm \mathrm{SE})$} \\
\hline & $4^{\text {th }}$ instar & $5^{\text {th }}$ instar & $6^{\text {th }}$ instar & prepupa & Pupa \\
\hline Methanol & $0.029 \pm 0.001^{\mathrm{a}}$ & $0.164 \pm 0.005^{\mathrm{a}}$ & $0.675 \pm 0.017^{\mathrm{a}}$ & $0.444 \pm 0.014^{\mathrm{a}}$ & $0.351 \pm 0.018^{\mathrm{a}}$ \\
\hline $\begin{array}{l}\text { Petroleum } \\
\text { ether }\end{array}$ & $0.032 \pm 0.004^{\mathrm{a}}$ & $0.158 \pm 0.004^{\mathrm{ab}}$ & $0.658 \pm 0.015^{\mathrm{a}}$ & $0.423 \pm 0.010^{\mathrm{ab}}$ & $0.352 \pm 0.009^{\mathrm{a}}$ \\
\hline Acetone & $0.028 \pm 0.001^{\mathrm{a}}$ & $0.139 \pm 0.004^{\mathrm{cd}}$ & $0.523 \pm 0.013^{c}$ & $0.399 \pm 0.011^{\mathrm{bc}}$ & $0.336 \pm 0.011^{\mathrm{ab}}$ \\
\hline Water & $0.031 \pm 0.002^{\mathrm{a}}$ & $0.133 \pm 0.004^{\mathrm{d}}$ & $0.589 \pm 0.018^{\mathrm{b}}$ & $0.393 \pm 0.011^{\mathrm{bc}}$ & $0.303 \pm 0.004^{\mathrm{c}}$ \\
\hline Diethyl ether & $0.025 \pm 0.0^{\mathrm{a}}$ & $0.132 \pm 0.006^{\mathrm{d}}$ & $0.572 \pm 0.015^{\mathrm{b}}$ & $0.377 \pm 0.009^{c}$ & $0.320 \pm 0.008^{b c}$ \\
\hline control & $0.030 \pm 0.005^{\mathrm{a}}$ & $0.147 \pm 0.004^{\mathrm{bc}}$ & $0.556 \pm 0.016^{\mathrm{bc}}$ & $0.369 \pm 0.011^{\mathrm{c}}$ & $0.319 \pm 0.011^{\mathrm{bc}}$ \\
\hline F. values & $1.170^{\mathrm{ns}}$ & $9.190^{* *}$ & $13.475^{* *}$ & $6.348^{* *}$ & $3.644^{* *}$ \\
\hline
\end{tabular}

However, methanol had rather high effect on the weight of this instar. The weight of the sixth instar was equally affected by water and diethyl ether.

Petroleum ether and methanol have the highest effect on the weight of the pupa, while water caused low effect resembling the control. However methanol had high effect on the prepupal weight. 


\section{DISCUSSION}

C. dactylon extracts showed to have similar properties to morphogenetics. When larvae of $S$. littoralis were fed on this grass extracts, some developed to giant larvae and deformed pupae. Similar abnormalities resulted from some upset in the balance of hormones during development had been shown in other insects by previous workers (Rhodnius, Wigglesworth (1964) and Trogoderma granarium, Azmy (1975).

Also the present results proved that this grass extracts also played a great role on number of eggs laid.

A vast amount of data has been published on the neuron-endocrine reproduction relations in female insects showing maturation and oviposition are controlled by different levels of hormonal activity of neurosecretory system (Azmy 1964).

The present treatments also lead some times to death; consequently this grass extracts could be used as antifeeding or insecticide. This is in agreement with the findings of Lynch et al., (1983) and Jamajanya (1987) in fall army worm.

More histological and physiological research work is needed to fine the characteristic features of each components of this grass extracts.

\section{REFERENCES}

Azmy, N. M. (1964). Studies concerning neurosecretion in the Khapra beetle Trogoderma granarium Everts. Ph.D. Thesis Uni. of London, 430pp

Azmy, N. M. (1975). The effect of farnesol on Trogoderma granarium Everts. Zeitshrift fur Angewandte Entomologie, 78:75-82.

Broza, M.; Brownbridge, M.; Hamal, M. and Sneh, B. (1991). Control of the African armyworm, Spodoptera exempta Walker (Lepidoptera: Noctuidae) in Kenyan fields with highly effective strains of Bacillus thuringiensis Berliner. BioControl Science and Technology, 1 (2):127-135.

Chang, N.T. (1986). Quantitative utilization of selected grasses by fall army worm (Lepidoptera: Noctuidae) larvae. Chinese J. Econ. Entomol., 6 (2): 163 - 175.

El-Gammal, A.M.; Karrar, A.H.; Mohamed, M.T. and Ghoneim, K.S. (1988). Antifeedant effects of some wild plants in eastern diserts of Egypt and Sudan to Schistcerca gregaria (Orthoptera: Acrididae). J. Fac. Education, AinShames Univ. 13:251-263.

El-Ibrashy, M. T. and Chenouda, M.S. (1970). Cholinesterase activity in Spodoptera littoralis Boisd. in relation to development and metamorphosis. Zeitschrift fur Angewandte Entomologie. 65:146-156.

Jamjanya, T. (1987). Consumption, utilization, biology and economic injury levels of fall armyworm, Spodoptera frugiperda (J.E.Smith), on selected Bermuda grasses. Dissertation Abstract, International B (Sciences and Engineering). 48(6)1590B.

Jamjanya, T. and Quisenberry, S. S. (1988). Fall armyworm (Lepidoptera: Noctuidae) consumption and utilization of nine Bermuda grasses. J. Econ. Entomol., 81(2):697-704.

Lynch, R.E.; Monson, W.G.; Wiseman, B. R. and Burton, G.W. (1983). Bermuda grass resistance to the fall armyworm (Lepidoptera: Noctuidae). Environ. Entomol. 12 (6): 1837-1840.

Lynch, R.E.; Monson, W.G.; Wiseman, B.R.; Burton, G.W. and Gaines, T. P. (1986). Relationship of forage quality to developmental parameters of the fall armyworm (Lepidoptera : Noctuidae). Environ. Entomol., 15 (4):889-893. 
Muellur, A. and Dumas, B.A. (1987). Host plants of the three cornered alfalfa hopper (Homoptera: Membracidea). Environ. Entomol., 16 (2): 513 - 518.

Negulescu, G.P. and Pisoschi, Z.M. (2008). Selenium and arsenic seleniumaccumulator plants. The Romanian Academy, Series B: Chemistry, Life Sciences and Geoscience. 10 (1-2):3-6.

Pashley, D.P. (1986). Host-associated genetic differentiation in fall armyworm (Lepidoptera: Noctuidae): a sibling species complex. Ann. Entomol. Soc. Amer., 79 (6):898-904.

Pashly D. P.; Hardy, T.N. and Hammond, A. M. (1995). Host effects on developmental and reproductive traits in fall armyworm strains (Lepidop[tera: Noctuidae). Ann. Entomol. Soc. Amer., 88(6): 748-755.

SAS Institute Inc (2003). SAS/STAT Version 8.2. SAS Institute Inc., Cary, NC.

Singh, S.; Rai, P.K.; Jaiswal, I. D.; Rai, D.K.; Sharma, B. and Watal, G. (2008). Protective effect of Cynodon dactylon against ( Stz ) sterptozotocin induced hepatic injury in rats. J. Ecophysi., \& Ocupational Health. 8 (3\&4): 195-199.

Walter, E.D. (1962). Isolation of B. sitosteral, B. sitosteryl, D. glucoside and palmitic acid from coastel bermuda grass and orcard grass. J. Pharmacitical Sci., 52 (7):708

Wigglesworth, V.B. (1964). Hormones and insect growth: review. Adv. Insect Physiol., 2: 243-332.

\section{ARABIC SUMMARY}

$$
\begin{aligned}
& \text { تأثير مستخلص النجيل على دودة ورق القطن } \\
& \text { نعمان بهاء الدين عارف } \\
& \text { قسم آفات ووقاية النبات ـ المركز القومي للبحوث }
\end{aligned}
$$

تم اختبار مستخلص نبات النجيل علي يرقات دودة ورق القطن العمر اليرقي الرابع، خاصة علي عملية الئية

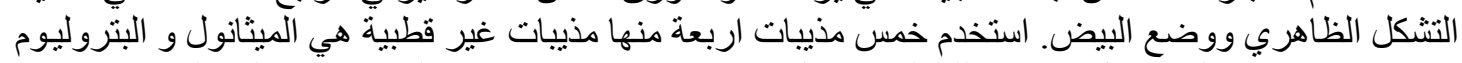

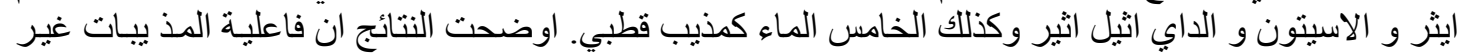

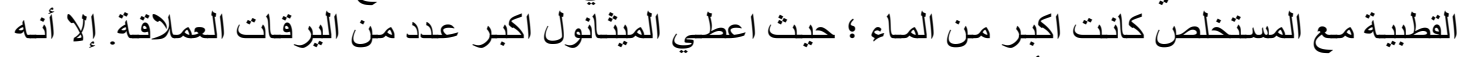

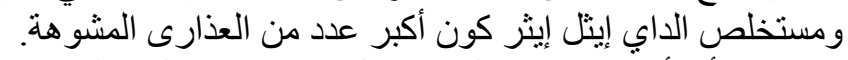

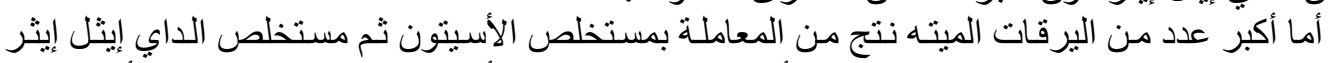

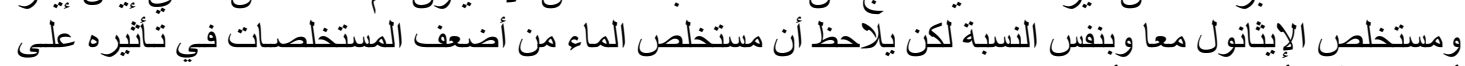

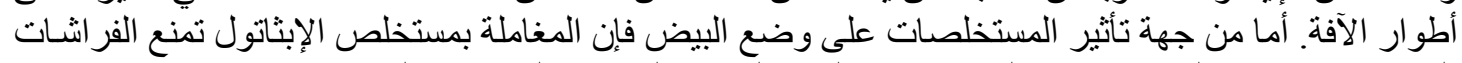

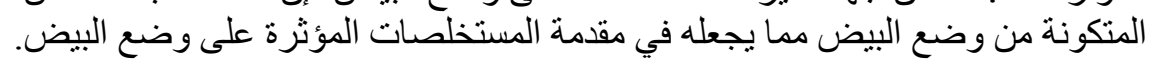

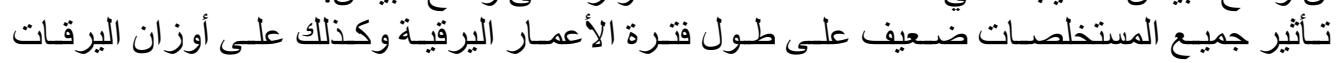
و العذارى الناتجة.

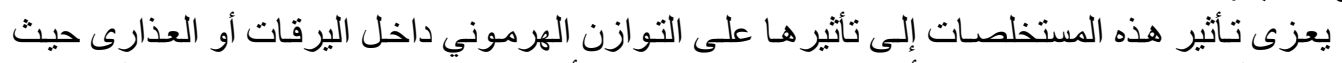

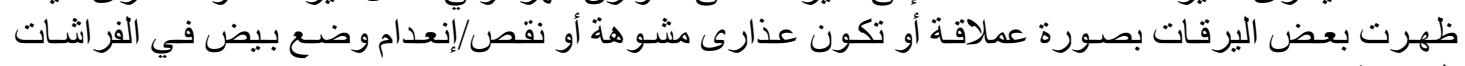

